\title{
Association européenne des chefs d'établissements du secondaire
}

Yves De Saint-Do

\section{OpenEdition}

12 Journals

Édition électronique

URL : http://journals.openedition.org/ries/4199

DOI : 10.4000/ries.4199

ISSN : 2261-4265

Éditeur

Centre international d'études pédagogiques

\section{Édition imprimée}

Date de publication : 1 décembre 1994

Pagination : 94

ISSN : 1254-4590

\section{Référence électronique}

Yves De Saint-Do, "Association européenne des chefs d'établissements du secondaire », Revue internationale d'éducation de Sèvres [En ligne], 04 | 1994, mis en ligne le 17 avril 2015, consulté le 06 janvier 2020. URL : http://journals.openedition.org/ries/4199 ; DOI : 10.4000/ries.4199

Ce document a été généré automatiquement le 6 janvier 2020

(c) Tous droits réservés 


\title{
Association européenne des chefs d'établissements du secondaire
}

\author{
Yves De Saint-Do
}

1 Le sigle (ESHA) ${ }^{1}$, un peu étrange, intrigue autant que l'association elle-même. Nombre de collègues mis pour la première fois en présence d'un bulletin d'ESHA-France ou d'un de ses adhérents s'interrogent sur l'origine, la composition, l'importance et les objectifs réels de ce nouvel organisme.

2 Rappelons les débuts, en novembre 1988, à Maastricht - déjà ! - quelques collègues britanniques, néerlandais, belges, allemands et français, réunis par le hasard de rencontres individuelles, à l'occasion d'une conférence sur le thème « l'éducation des Européens de demain " décident de créer une association européenne de chefs d'établissements secondaires.

3 Les objectifs sont ainsi définis : «Promouvoir l'idée d'une Europe unie des personnels de direction de l'enseignement secondaire, développer leur connaissance des aspects historiques, culturels, économiques et sociaux de l'Union européenne ».

$4 \mathrm{Au}$ fil des ans, ces ambitions se sont élargies, autant que possible, à l'ensemble des élèves, des professeurs des lycées et collèges.

5 Lancée en novembre 1991, ESHA-France a grandi après un démarrage un peu difficile et compte aujourd'hui 300 adhérents individuels et deux associations de personnels de direction, le SNPDEN et la FNPAES. C'est une association non gouvernementale, indépendante, riche des seules cotisations et du dévouement de ses adhérents.

6 Rassemblant des sensibilités très diverses dans un climat d'amitié, désirant travailler ensemble à une œuvre commune dont les enfants et les adolescents doivent être les premiers bénéficiaires, l'engagement européen de l'association permet de rompre un certain isolement, de contribuer à mettre en synergie des initiatives et des projets d'une infinie richesse, tant à l'ouest qu'à l'est, par des rencontres, des séminaires et des échanges. 


\section{NOTES}

1. ESHA : European Secondary Heads Association.

\section{AUTEUR}

YVES DE SAINT-DO

Proviseur, Lycée Louis-le-Grand, président de l'ESHA-France, Paris 